\title{
Evaluation of Spatial-Temporal Variations of Water Quality and Plankton Assemblages and Its Relationship to Water Use in Kulekhani Multipurpose Reservoir, Nepal
}

\author{
Puspa L. Adhikari ${ }^{*}$, Sagar Shrestha ${ }^{2 \#, ~ W o k i l ~ B a m ~}{ }^{3}$, Lin Xie ${ }^{4}$, Peter Perschbacher ${ }^{5}$ \\ ${ }^{1}$ Department of Environmental Sciences, Louisiana State University, Baton Rouge, USA \\ ${ }^{2}$ Department of Physical and Environmental Sciences, Texas A \& M University-Corpus Christi, Corpus Christi, USA \\ ${ }^{3}$ Department of Oceanography and Coastal Sciences, Louisiana State University, Baton Rouge, USA \\ ${ }^{4}$ Aquaculture/Fisheries Center, University of Arkansas at Pine Bluff, Pine Bluff, USA \\ ${ }^{5} 210$ River Gate Lane, Wilmington, USA \\ Email: *padhik2@lsu.edu, *puspa.adhikari@gmail.com, \#sshrestha1@islander.tamucc.edu
}

How to cite this paper: Adhikari, P.L., Shrestha, S., Bam, W., Xie, L. and Perschbacher, P. (2017) Evaluation of Spatial-Temporal Variations of Water Quality and Plankton Assemblages and Its Relationship to Water Use in Kulekhani Multipurpose Reservoir, Nepal. Journal of Environmental Protection, 8, 1270-1295. https://doi.org/10.4236/jep.2017.811079

Received: September 6, 2017

Accepted: October 16, 2017

Published: October 19, 2017

Copyright $\odot 2017$ by authors and Scientific Research Publishing Inc. This work is licensed under the Creative Commons Attribution International License (CC BY 4.0).

http://creativecommons.org/licenses/by/4.0/

\begin{abstract}
Spatial and temporal variation in planktons and water quality parameters were investigated in order to determine the effects of seasonal water use on reservoir water quality and planktons' diversity in Kulekhani Multipurpose Reservoir, Nepal. This study also focuses on interactions among various water quality parameters with planktons and how such interactions can affect the second major utility, the fish farming in the reservoir. The analyses of seasonal water samples collected from three different sampling locations in the reservoir showed that select water quality parameters varied significantly $(\mathrm{P}<$ 0.05 ) with sampling seasons (transparency: $30-250 \mathrm{~cm}, \mathrm{pH}: 7-7.5$, alkalinity: $30-120 \mathrm{mg} / \mathrm{L}, \mathrm{DO}: 6-11.5 \mathrm{mg} / \mathrm{L}, \mathrm{CO}_{2}: 0.1-1.1 \mathrm{mg} / \mathrm{L}$ ) and sampling locations (phosphate: $0.1-0.25 \mathrm{mg} / \mathrm{L}$, nitrate $0.01-0.19 \mathrm{mg} / \mathrm{L}$ ) in the reservoir. Three groups of zooplankton and four classes of phytoplankton, respectively with eleven and twelve genera, were identified and quantified in the reservoir. Among them, Cyclops, Asplanchana, and Keratella were most dominant zooplanktons while Synedra, Melosira and Peridinum were the most dominant phytoplankton in the reservoir water. The abundance of select zooplanktons (Cyclops, Keratella, Polyanthra), and phytoplankton (Navicula, Melosira, Amphora, Chroococcus, Staurastrum, Scendesmus) showed significant interaction between sampling sites and sampling seasons, while the other varied only with sampling seasons and/or sites. These results showed that seasonal water level fluctuations, along with the variation of water quality para-
\end{abstract}


meters, change the abundance and diversity of planktons' in the reservoir. Such changes can negatively impact the fish in cage culture, affecting the livelihood of people extensively relying on these fish farming.

\section{Keywords}

Kulekhani Multipurpose Reservoir, Water Quality, Planktons, Aquaculture, Cage Culture, Hydroelectric Reservoir in Nepal

\section{Introduction}

Kulekhani Multipurpose Reservoir is located at $~ 1500 \mathrm{~m}$ above the sea level, in between the latitudes $27.683 \mathrm{~N}$ and $27.584 \mathrm{~N}$, and longitudes $85.305 \mathrm{E}$ and $85.040 \mathrm{E}$ in Kulekhani watershed area, Central Nepal (Figure 1) [1] [2]. The reservoir was constructed in 1981 by impounding Kulekhani River water behind a $114 \mathrm{~m}$ high dam, with a capacity of 73.3 million $\mathrm{m}^{3}$ live volume [3]. It receives water as well as a large amount of sediments and nutrients from $126 \mathrm{~km}^{2}$ of watershed (largely agricultural land with elevation between $1534-2621 \mathrm{~m}$ above the sea level) [1]. While the reservoir stores water throughout the year, a major fraction of the water $(\sim 80 \%)$, sediments and nutrients are collected during the Monsoon season, between June and September [3] [4]. The stored water in the reservoir is primarily

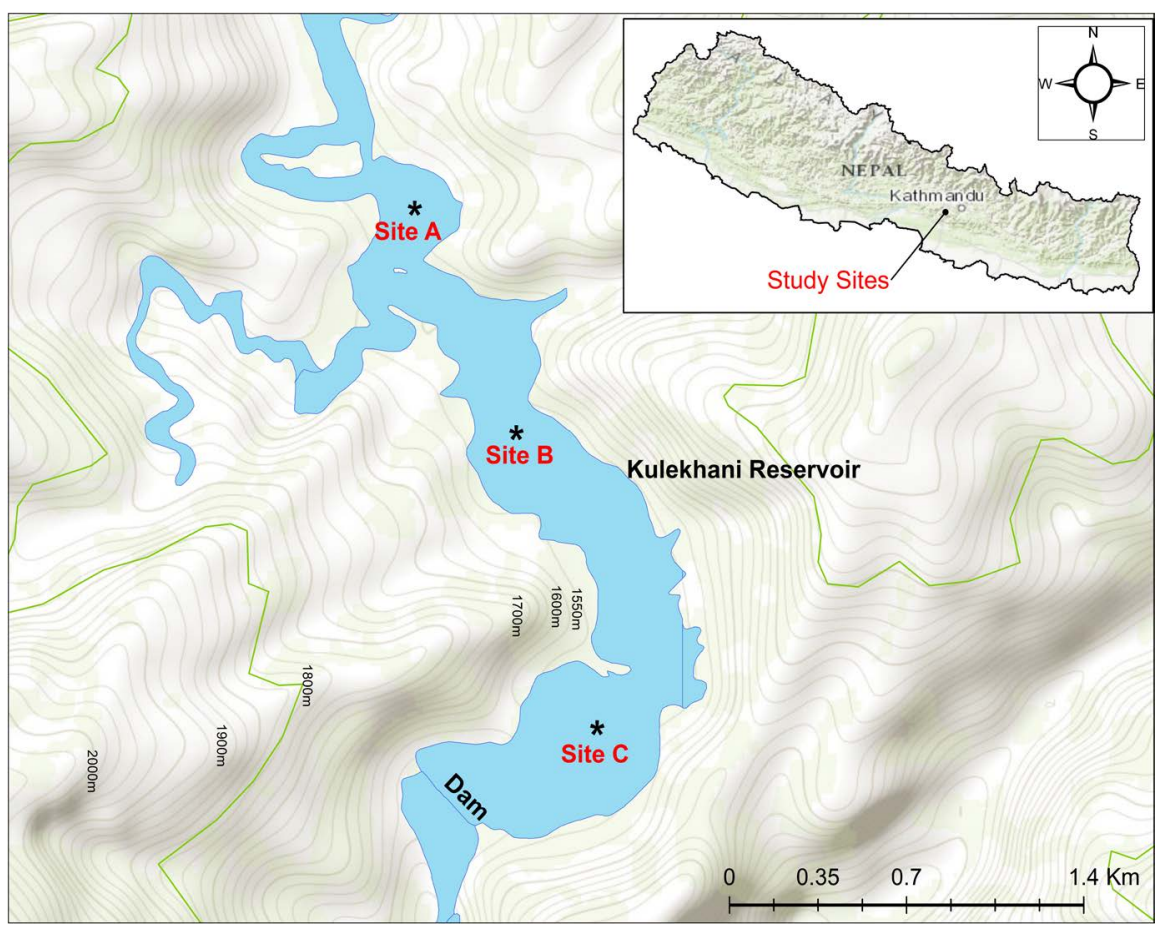

Figure 1. Sampling locations in the Kulekhani Multipurpose Reservoir, Nepal. Site A: upper reach of the reservoir, Site B: middle reach, and Site C: within the fish farming (cage culture) area near the dam. Kulekhani Multipurpose Reservoir is located at $~ 1500$ $\mathrm{m}$ above the sea level, in between the latitudes $27.683 \mathrm{~N}$ and $27.584 \mathrm{~N}$, and longitudes 85.305E and 85.040E in Central Nepal. 
used for hydroelectric power generation during the dry months (November-April) in Nepal, providing a significant $(\sim 18 \%)$ amount of the electric power to the whole country [5]. In addition to the seasonal power generation, the reservoir water is also extensively used for fish farming, as a cage culture, throughout the year [6]. This cage fish farming is one of the major sources of economy for people living near the Kulekhani Reservoir, especially for a significant number of people among the $\sim 500$ households displaced by the construction of the reservoir in 1981 [7]. The daily use of reservoir water for power generation results in large fluctuation of the water level (between $53-80 \mathrm{~m}$ ) and area of the water (between 65-220 ha) in the reservoir. Such daily and seasonal water uses and water level fluctuations depend on the hydroelectric power demand of the country, higher during high demand season (summer) and time of the day (evening) [4] [8].

The Kulekhani Reservoir is a typical example of multipurpose impoundments, where the proper management and utilization of the reservoir water for one purpose without hampering the other is always challenging. Some of these management challenges are change in water quality, water volume and depth, excessive nutrient and sediment loads, and reservoir eutrophication. For instances, the increased sediment loading has already reduced the total capacity of reservoir by 10 million $\mathrm{m}^{3}$ ( 25\% of its capacity in 30 years) [9]. These sediment loadings, along with decreased river inputs due to the effects of climate change and increase in land use for agricultural purposes, have significantly reduced the power generation capacity of the reservoir, and will be significantly lower in near future [10]. The decrease in reservoir's storage capacity also results increase in fluctuation of water level during peak water use period.

The seasonal and daily (both the long- and short-term) fluctuations in water supply and uses, thermal stratification, and nutrients and sediment loads from the agricultural activities also affect the reservoir water quality. It is well known that the occurrence of aquatic plant and animal species in lakes and reservoirs is closely related to its water chemistry [11]. Thus, any change in water quality in the reservoir in response to the water level fluctuations can alter the plankton community composition/productivity, which can ultimately affect the reservoir fisheries and the livelihood of the people dependent upon these cage culture. For instance, the change in food and habitat in Kulekhani Reservoir has already caused disappearances of some indigenous fish fauna that were present before damming [12]. Moreover, an excessive accumulation of sediments (700 $\left.\mathrm{m}^{3} / \mathrm{km}^{2} / \mathrm{y}\right)$ [13], associated nitrogen $(48,459 \mathrm{~kg} / \mathrm{yr})$ and phosphorus $(2907 \mathrm{~kg} / \mathrm{yr})$ since the beginning of the reservoir [14] [15] have significantly affected the reservoir's depth, water quality, and flora and fauna's diversities. Nevertheless, the stakeholders are mostly unaware of the potential effects of such change in water quality/quantity, both long and short-term, and reservoir plankton's community composition on their fish farming and ultimately their major source of economy.

Rapid increase in demands for electricity due to increase in population and 
industries have forced the government of Nepal to extensively search for new sources of electricity. Such a rapidly increasing power demand [16] and lack of other major alternative sources of power generation (e.g., nuclear, and thermal power plants) has already made the government to invest more on hydroelectricity. As a result, a number of hydroelectric power plants have been already approved/ started in Nepal, and the government is planning for more to begin in near future [17]. Therefore, the chances of construction of hydropower in Nepal are very high, which will create a large number of such constructed wetlands in Nepal in near future.

Construction of a dam across the naturally flowing stream causes a fragmentation of lotic water body that changes the physico-chemical parameters of the water, hinders fish migration, and ultimately causes adverse effects on aquatic ecosystem [18]. It also changes the composition of the planktons, the food for fishes, and the change in their composition can change the fish production and diversities, one of the most important natural resources of Nepal. Thus, it is imperative to thoroughly investigate the changes in water quality and planktons' community composition in response to water uses and fluctuations in the constructed wetlands, including the Kulekhani Reservoir. Such studies are also very critical in determining how the spatial and temporal variations in water quantity and quality can affect the fish farming and the livelihood of the reservoir depended population. However, to the best of our knowledge, a very few limnologic studies have been conducted in Nepal in general and more specifically in the Kulekhani Reservoir, during past four decades after the construction of the reservoir in 1981 [19] [20]. In order to fulfill this knowledge gap, the present study aims to investigate the present status of floating flora and fauna (planktons) in the Kulekhani Reservoir, and to determine the relationship between zooplankton and phytoplankton in the reservoir. This study also focuses on interactions among various water quality parameters with planktons (zooplankton and phytoplankton) and how such interactions can affect the second major utility (the fish farming) of the Kulekhani Multipurpose Reservoir.

\section{Materials and Methods}

\subsection{Study Area}

The Kulekhani watershed is comprised of $43.6 \%$ forest, $34 \%$ sloping agricultural land, 9.2\% shrub, 5.7\% level and valley terraces, and 7.5\% other land uses [21]. Total population of Kulekhani Watershed was 31,562 , with more than $80 \%$ of them depending on agriculture for their livelihood [22]. Among them, 239 households have been involved in fish culture in 1630 cages in 2009 [10]. The climate of Kulekhani watershed varies from subtropical at low land to temperate at higher elevation [4]. The average summer temperature of Kulekhani watershed is $15^{\circ} \mathrm{C}$ to $25^{\circ} \mathrm{C}$ whereas the winter average temperature is $10^{\circ} \mathrm{C}$ to $15^{\circ} \mathrm{C}$ (2) It has four distinct seasons namely; pre-monsoon (March to May), monsoon (June to September), post monsoon (October to November) and winter (De- 
cember to February). The reservoir receives $\sim 1400 \mathrm{~mm}$ of rainfall in the monsoon season and $\sim 60 \mathrm{~mm}$ during other dry seasons, and water level in the reservoir varies with season and power generation [15].

\subsection{Sampling Sites}

Water samples for the analyses of water quality parameters and planktons were collected from three sites, namely Site A (upper reach of the reservoir), Site B (middle reach), and Site $C$ (lower reach around cage culture) in the Kulekhani Reservoir during eight months (February, March, May, June, July, August, September and October) in 2007 (Figure 1). Site A represents a natural river inflow environment with minimal reservoir impacts, and the water quality and plankton's community composition before and sometimes immediately after (depending upon the season) the impoundment of the river water. While the Site A turned into a river channel during dry and high-power demand season, it was impounded during the high-flow low-demand seasons. Site B, approximately at the middle of the reservoir, was flooded/impounded throughout the sampling seasons and was not directly affected by the cage culture activities. Site C, near the dam, was also always impounded and was represents an area heavily affected by aquaculture activities (cage culture).

\subsection{Sample Collection and Analyses}

\subsubsection{Water Quality}

Water temperature $\left({ }^{\circ} \mathrm{C}\right), \mathrm{pH}$, transparency $(\mathrm{cm})$ and conductivity $(\mu \mathrm{S} / \mathrm{cm})$ were measured in situ. Similarly, dissolved oxygen (DO), free carbon dioxide $\left(\mathrm{CO}_{2}\right)$, alkalinity and hardness were analyzed in the field, immediately following the sample collection, using standard wet titration methods explained elsewhere in detail [23] [24] [25]. Water samples for the analyses of nitrate, and phosphate were collected in 1-L acid-washed plastic bottles, transported on ice and stored at $-4^{\circ} \mathrm{C}$ until lab analysis. The samples for phosphate and nitrate were analyzed using the acid per sulfate digestion and the cadmium reduction method, respectively [23].

\subsubsection{Zooplankton and Phytoplankton}

For the identification and estimation of zooplankton and phytoplankton, $10 \mathrm{~L}$ of surface water was collected by using plastic bucket, filtered through plankton net having bolt-silk no. 30, diluted by adding $20 \mathrm{~mL}$ deionized water and then transferred into the plankton tube. The samples were then preserved in formalin solution and brought to lab for further analyses. The quantitative analysis of the planktons was done with the help of a Sedgwick-Rafter Cell [26] under microscope and the qualitative analysis was done under a microscope of $(10 \times 15) 150$ magnifications. The identification of the planktonic organisms to genus level was done in the lab following the standard protocol [27] [28]. Density estimations (individuals/volume of water samples), ind./L for zooplanktons and ind./mL for phytoplankton were also conducted. 
Shannon-Wiener diversity index (H') [29] was used to measure the diversity (genera) of zooplankton and phytoplankton in all three sites over the whole study period.

$$
H^{\prime}=-\sum_{i=1}^{s}\left(p_{i}\right) \log p_{i}
$$

where $p_{i}=n_{i} / N, N=$ total number of individuals on sample and $n_{i}=$ the number of individual genera in the sample, where $i=$ genera number and $S$ is the total number of genera.

\subsection{Statistical Analyses}

The Kolmogorov-Smirnov test and Levene's test were used to check normality and homoscedasticity assumptions prior to analysis. Parameters with unequal variances were either $\log 10(x+1)$ or square root transformed. The water quality and plankton data were then analyzed by two-way repeated measure ANOVAs (site [three levels], month [eight levels]) with Tukey's 1 degree-of freedom test for no additivity [30] using PROC MIXED in SAS (SAS institute Inc. Cary, NC, USA). Tukey HSD post hoc tests were applied in the presence of significant main effect. One of the zooplanktons (Filina) was excluded from statistically analyses because of its rare presence. Multivariate statistical models, principal component analysis (PCA) and canonical correlation analysis (CCA), were also used to analyze the data. All the statistical analyses were done in JMP (SAS Institute, Inc. Cary, NC) and R. Level of significance was set at $\alpha=0.05$ for all the tests.

\section{Results and Discussion}

\subsection{Water Quality Characterization}

The surface water temperature, $\mathrm{pH}$ and transparency varied between $13.3^{\circ} \mathrm{C}$ $25.5^{\circ} \mathrm{C}, 7.3-9.5$, and $32-246 \mathrm{~cm}$, respectively. Similarly, $\mathrm{DO}, \mathrm{CO}_{2}$, alkalinity, total hardness, nitrate, and phosphate varied between $6.3-11.1 \mathrm{mg} / \mathrm{L}, 0.01-1.1$ $\mathrm{mg} / \mathrm{L}, 38-112 \mathrm{mg} / \mathrm{L}, 36-88 \mathrm{mg} / \mathrm{L}, 0.01-0.19 \mathrm{mg} / \mathrm{L}$, and $0.1-0.26 \mathrm{mg} / \mathrm{L}$, respectively. The water quality parameters varied considerably among the sampling stations in the reservoir throughout the sampling periods (Figure 2). However, there was no significant interaction effects $(\mathrm{P}>0.05)$ of sampling periods and sampling locations (i.e. no months ${ }^{*}$ sampling sites interactions effects) on variation in these water quality parameters, except for transparency and alkalinity (Table S1, Figure 2). These results indicate that the variation in water quality parameters in the reservoir is a unique effect i.e., the effect of seasons on water quality parameters is not significantly different among the sampling stations and vice versa. As the interaction effects were not significant, the unique effects of months and sampling sites were evaluated for each water quality parameters (Tables S1-3). The results showed that temperature, $\mathrm{pH}, \mathrm{DO}$, and free $\mathrm{CO}_{2}$ varied significantly $(\mathrm{P}<0.05)$ among the sampling periods, while nitrate 

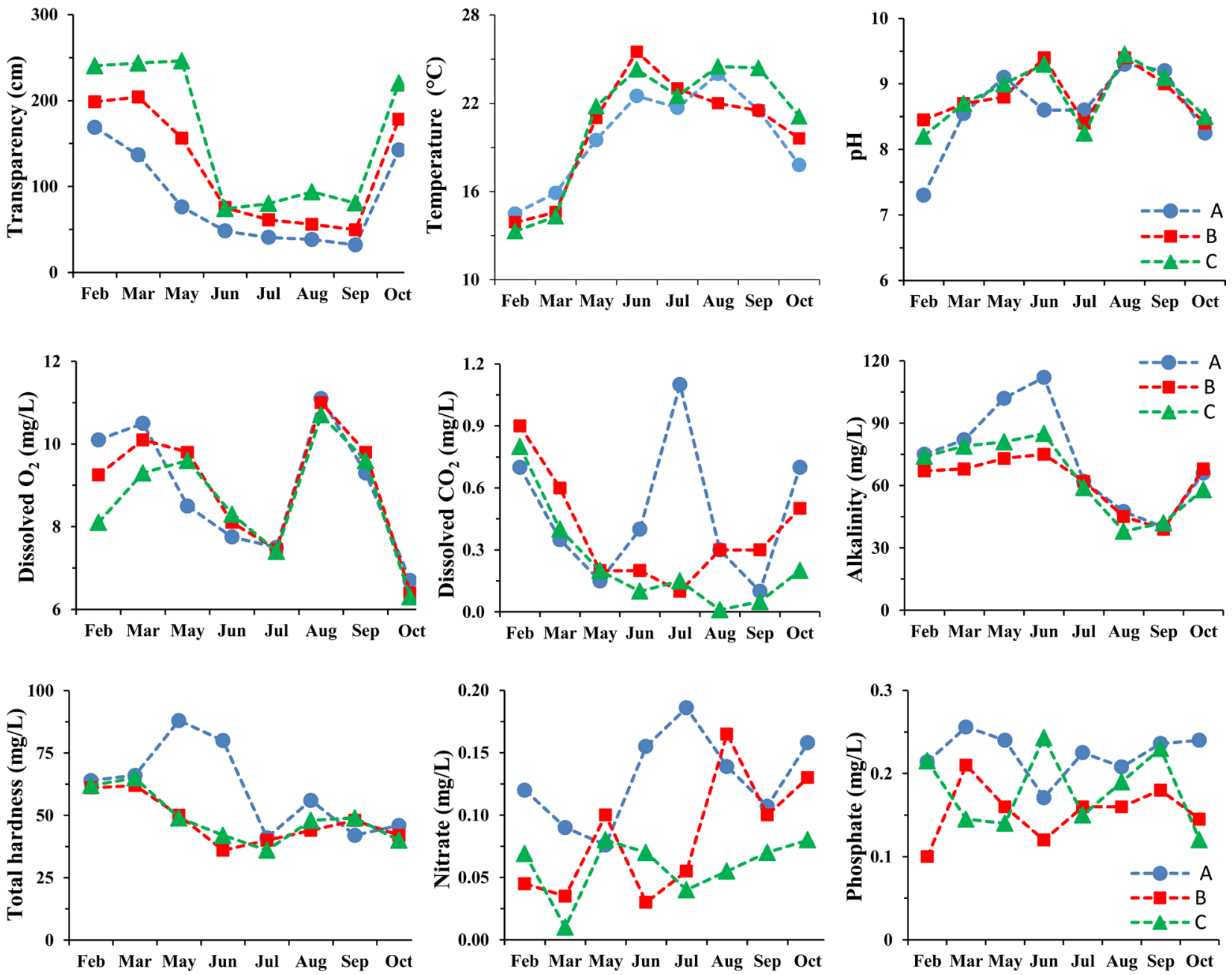

Figure 2. Spatial and temporal variation of water quality parameters at three different sampling locations in Kulekhani Reservoir, Nepal during the study period. The Blue circles, Red squares and Green triangles represent study sites, Site A, Site B, and Site C, respectively.

and phosphate varied significantly among the sampling stations (Figure 2, Table S2, Table S3).

Water temperature is one of the most important limnologic parameters which influences all the other parameters directly or indirectly. The surface water temperature in the Kulekhani Reservoir followed similar pattern of air temperature throughout the sampling periods. It supports that the seasonal variation in surface water temperature of a reservoir or lake is strongly affected by the atmospheric temperature of the catchment area [9] [31]. Like the water temperature, $\mathrm{DO}$ is another critically important water quality parameter which is often used as a pollution indicator of an aquatic ecosystem. The surface water DO in the Kulekhani Reservoir was always $>6.3 \mathrm{mg} / \mathrm{L}$, which showed that the reservoir water had sufficient oxygen levels for the survival of aquatic life, and also indicates the level of organic pollution in the reservoir is considerably low. The average DO in the reservoir water was found to be highest $(11.0 \pm 2.2 \mathrm{mg} / \mathrm{L})$ in August and lowest $(6.5 \pm 0.2 \mathrm{mg} / \mathrm{L})$ in October (Figure 2). Comparatively, higher con- 
centrations of DO in August can be attributed to higher photosynthetic activities at favorable temperature. In contrast, the low DO content in the surface water during July, and immediately after the rainy season, was probably due to the flooded water containing high amount of silt loaded in the catchment area of the reservoir [9] [20]. Similar to the DO levels, slightly alkaline reservoir water with $\mathrm{pH} 8.8 \pm 0.5$ (always $>8.2$, except for Site A in February, Figure 2) was found to be most suitable for fisheries, and for the growth and development of various aquatic organisms [32]. As expected, $\mathrm{CO}_{2}$ in this study was found to be relatively low throughout the study period, which was due primarily to relatively higher concentrations of DO, and low level of organic pollution in the reservoir water throughout the study period.

Unlike other water quality parameters, significant months ${ }^{\star}$ sampling sites interaction effects were observed for transparency and alkalinity (Table S1, Figure 2). Water transparency had an average value of $0.85,1.22$ and $1.60 \mathrm{~m}$ in Site A, Site B and Site C, respectively, and was higher in February-March but dropped to lowest in July-September (Figure 2). The lower transparency of the reservoir water in June-September was primarily due to the runoffs of sediment laden rain water in to the reservoir, and also due to the increase in phytoplankton density in the reservoir. The transparency of Site $\mathrm{C}$ was always higher than Site A and Site B. The lower transparency at Site A than other sites was mainly attributed to its location in the upper reach of the reservoir which is largely affected by the sediment load carried by the feeding streams [19]. The observed spatial and temporal variation in transparency can also be due to other factors including the growth of planktons, material derived from the shore by wave action, erosion, the amount of wind induced turbulence keeping material in suspension, the settling of suspended particles introduced by the river inflow [19] [33].

The mean annual alkalinity observed in the present study $(66.6 \pm 18.7 \mathrm{mg} / \mathrm{L})$ was within the range of "very productive" $51-67 \mathrm{mg} / \mathrm{L}$ [34], and high productivity $>40 \mathrm{mg} / \mathrm{L}$ [35] water bodies. Alkalinity showed seasonal variations in all sampling sites, higher in February-June followed by a decrease from July-September (Figure 2), which is a typical trend in this region [10]. In contrast to alkalinity, total hardness $(52.4 \pm 13.3 \mathrm{mg} / \mathrm{L})$ in the reservoir water was relatively constant among sampling sites, and throughout the sampling periods (Figure 2). Calcium hardness attributed to more than $80 \%$ of total hardness, which is similar to the previously reported hardness distribution in the Kulekhani Reservoir [19]. Based on the observed concentrations of total hardness in the reservoir water, the $\mathrm{Ku}$ lekhani Reservoir can be classified as a soft water body (i.e., with total hardness $0.00-75 \mathrm{mg} / \mathrm{L}$ ). Thus, the reservoir water is suitable for fisheries, with total hardness $\geq 15.0 \mathrm{mg} / \mathrm{L}[32]$.

In contrast to the majority of the other water quality parameters, no significant seasonal variations were observed in phosphate and nitrate concentrations in the reservoir water. However, the phosphate and nitrate concentrations were significantly higher at Site A than both Sites B and Site C (Figure 2, Table S3). 
The productivity of an aquatic ecosystem largely depends on the concentration of these two macronutrients, phosphorus $(\mathrm{P})$ and nitrogen $(\mathrm{N})$. In number of lakes and reservoirs, the phytoplankton's productivity is primarily limited by available $\mathrm{P}$, thus, an increase in $\mathrm{P}$ concentration can result in eutrophication of these water bodies [36]. Traditionally, water bodies are $\mathrm{N}$ rich and $\mathrm{P}$ limited, thus, $\mathrm{P}$ is generally regarded as the major nutrient controlling primarily productivity [37]. However, $\mathrm{N}$ can also be either primary or co-limiting nutrient for phytoplankton production in some of the lakes and reservoirs [38] [39]. Unlike many other $\mathrm{P}$ limited lakes and reservoirs, the observed concentrations of phosphate in the Kulekhani Reservoir was much higher than the normal range (0.1 $0.2 \mathrm{mg} / \mathrm{L}$ ) for maintaining phytoplankton's life cycle [40]. A large amount of nitrate is potentially accumulated in the Kulekhani Reservoir via floodwater run-off, atmospheric depositions, inflow of organic matters and the bacterial decomposition of both allochthonous and autochthonous organic matters. Interestingly, the reservoir water had relatively higher phosphate levels during the study period which is likely due to the preferential microbial activities as they change organic forms of $\mathrm{P}$ into inorganic soluble orthophosphate. Moreover, the reservoir receives water from the large catchment area and water flows through the settlement and heavily agricultural areas, thus, the $\mathrm{P}$ from the soap and other animals' wastes could be main reason for such high phosphate levels in the reservoirs. It is also likely that the higher phosphate concentrations could be due to the use of agricultural fertilizers loaded with $\mathrm{P}$ in the watershed [41] followed by agricultural runoffs into the reservoir.

\subsection{Plankton Distribution}

Three groups of zooplanktons (Copepoda, Cladocera and Rotifers), with eleven genera and Nauplius larvae, and four classes of phytoplankton (Chrysophyta, Cyanophyta, Chlorophyta and Pyrrophyta) with twelve genera were identified and quantified in the Kulekhani Reservoir water. The list of both the zooplankton and phytoplankton identified in this study are presented in supplemental document (Table S4).

The average zooplankton density in the reservoir water was $494 \mathrm{ind} . / \mathrm{L}$, and varied from 235 in February to 743 ind./L in July (Figure 3). The group Rotifers (48.19\%) was most the abundant zooplanktons in the reservoir, followed by Copepoda (36.38\%), while Cladocera had the lowest abundance (15.57\%) in the reservoir water. Among the eleven genera of the zooplanktons, Cyclops was most abundant, with $25 \%$ contribution in all three sites, which was followed by $A s$ planchana (19.94\%) and Keratella (13.17\%) while Filina (0.025\%) was least abundant followed by Alona (0.45) (Table 1, Figure 4,). The zooplankton communities showed different patterns of temporal and spatial variations during the whole study period, however, zooplankton's density was generally lower in a downriver direction, except in October, (Table 1 and Table 2, Figure 4). Among all the eleven zooplanktons' genera, Cyclops, Keratella, and Polyanthra 

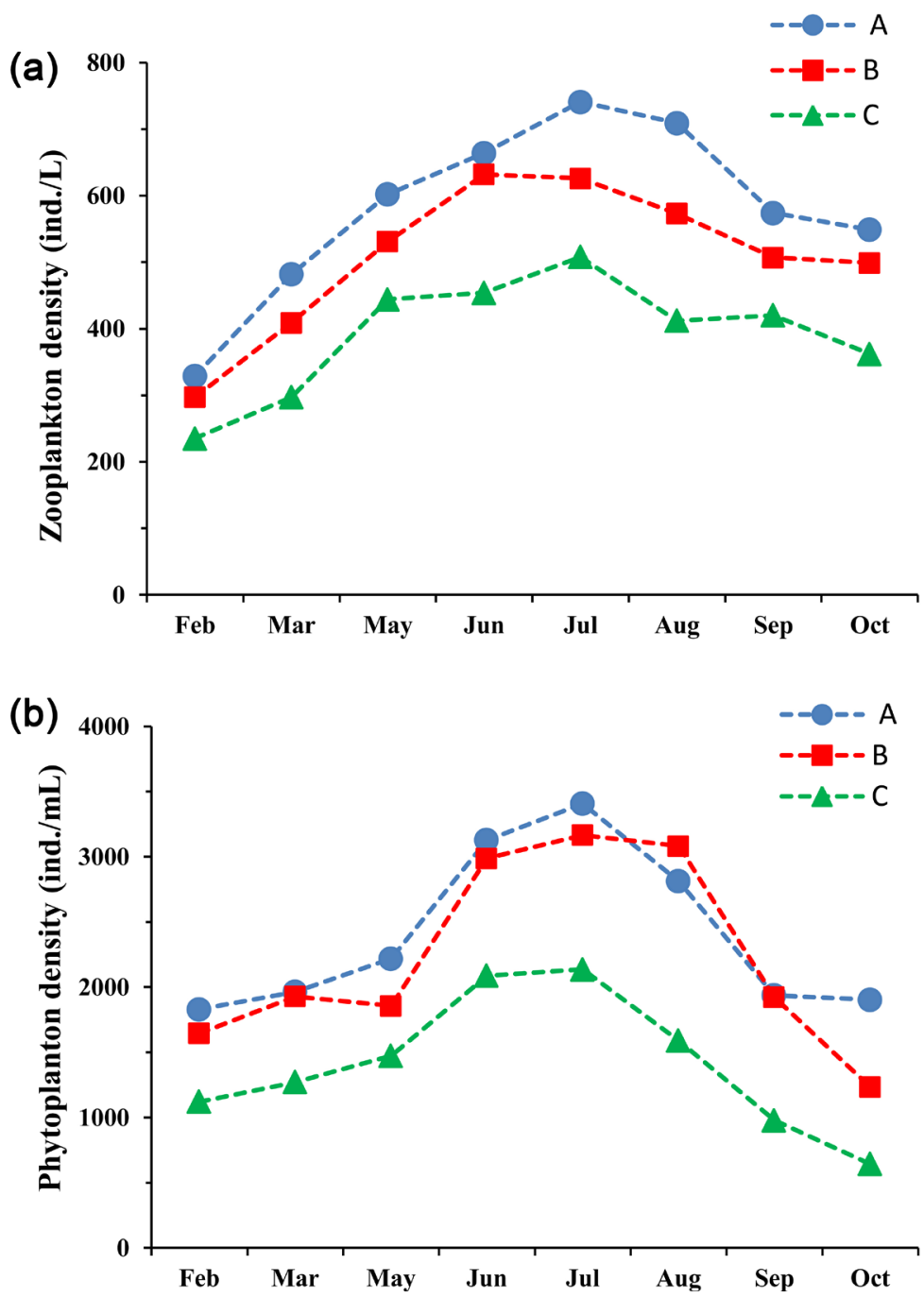

Figure 3. Distribution of zooplankton (a) and phytoplanton (b) in the Kulekhani Reservoir, Nepal during the study period. The Blue circles, Red squares and Green triangles represent study sites, Site A, Site B, and Site C, respectively.

showed a significant months ${ }^{\star}$ sampling sites interaction effects (Figure 3). In contrast, seasonal variations were observed for Nauplius, Daphnia, Bosmina, Alona, Moina, Pompholyx, Asplachana, and Brachionus (Table 1 and Table S5). Similarly, a significant variation was observed among the sampling stations for the zooplankton Nauplius, and Daphnia, Pompholyx, Bosmina, Asplachana, Alona and Brachionus (Table 2 and Table S5).

The average phytoplankton density of the reservoir water was $2014 \mathrm{ind} . / \mathrm{mL}$. Like the zooplanktons, the abundance of the total phytoplankton also varied significantly among the sampling stations, Site A and Site B were significantly different than Site C in terms of total phytoplankton (Figure 3). The total phytoplankton density was significantly higher in May-August than the other sampling months (Figure 3). Among the four groups of the phytoplanktons, Chryssophyta was found to be with highest number of genera as well as individuals comprising $72.29 \%$ of the total phytoplankton in the reservoir. Among the twelve 

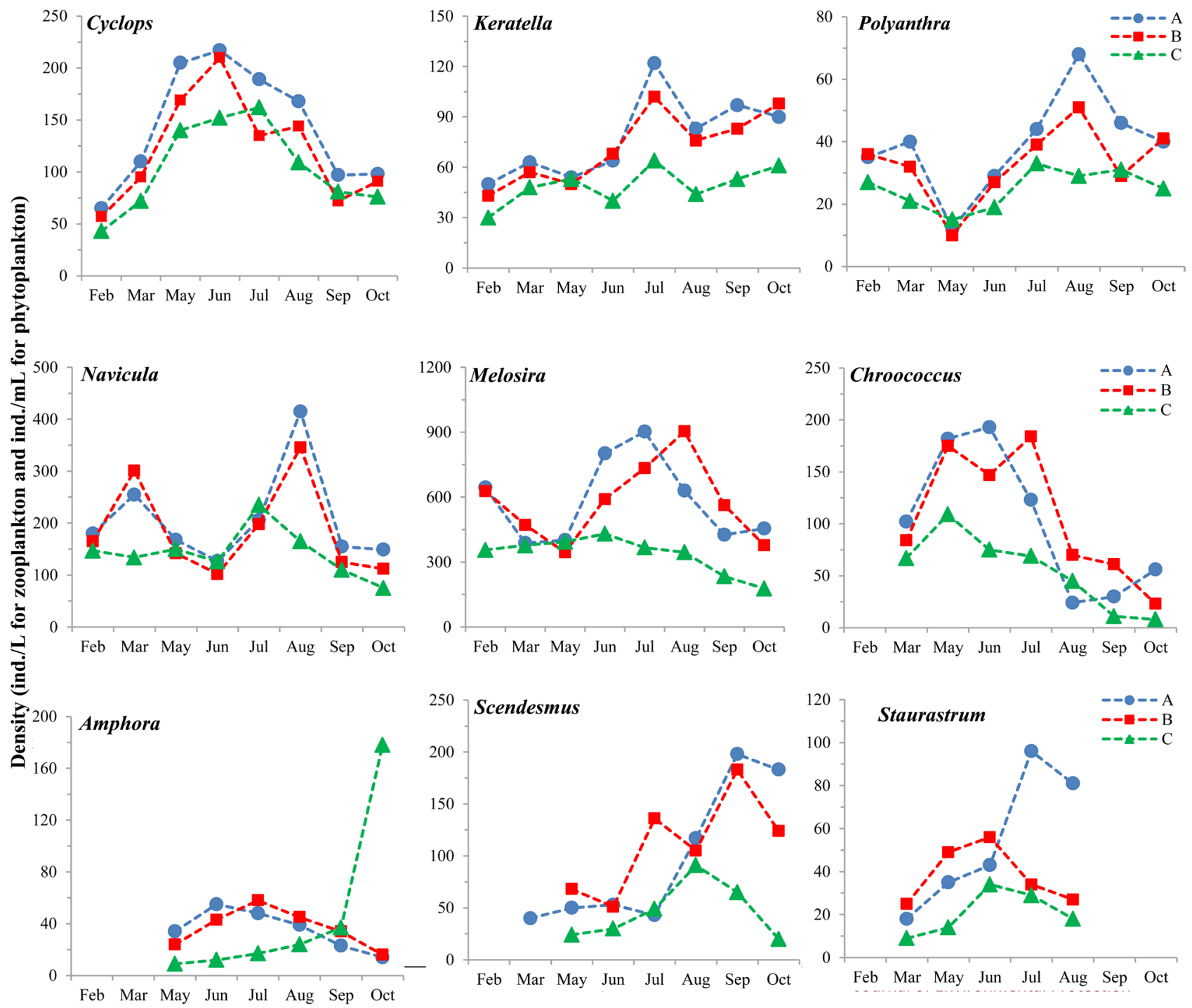

Figure 4. Distribution of select genera of zooplanktons and phytoplankton in the Kulekhani Reservoir, Nepal during the study period. These selected planktons showed statistically significantly $(\mathrm{P}<0.05)$ interaction effects among the sampling periods and sampling sites (i.e., months ${ }^{\star}$ sampling sites interaction effects), on their distribution in the reservoir. The Blue circles, Red squares and Green triangles represent study sites, Site A, Site B, and Site C, respectively.

genera of phytoplankton, Synedra (34.85\%) was most dominant phytoplankton followed by Melosira (24.56\%), and Fragilaria (0.475\%) was the rarest genera followed by Amphora (1.09\%). Similar to the zooplankton, significant interactions were also observed for phytoplankton genera Navicula, Melosira, Amphora, Chroococcus, Staurastrum and Scendesmus (Table S6, Figure 4). Density of Synedra and Anabaena, varied among the months and study sites (Table 1, and Table 2), while Anabaena, Peridinium and Synedra differed significantly among sampling station (Table 1, and Table S6).

Among all the three sites, Site A had the highest number of zooplanktons (39.3\%) and phytoplankton (40.8\%), followed by Site B (respectively, $34.2 \%$ and $35.2 \%$ ), and with lowest percentage in Site C (respectively, 26.5\% and 24.0\%). The higher phytoplankton's density at Site A was likely due to large amount of 
Table 1. Monthly distribution of zooplankton and phytoplankton (mean \pm SD) in Kulekhani Reservoir, Nepal. Means in rows with common letters are not significantly different; $\mathrm{P}>0.05$.

\begin{tabular}{|c|c|c|c|c|c|c|c|c|}
\hline & Feb & Mar & May & Jun & Jul & Aug & Sept & Oct \\
\hline \multicolumn{9}{|c|}{ Zooplankton (ind./L) } \\
\hline Nauplius & $29(5) \mathrm{c}$ & $31(9) c$ & $46(9) \mathrm{b}$ & $67(12) a$ & $60(10) a b$ & $71(30) a$ & $73(11) \mathrm{a}$ & $71(5) \mathrm{a}$ \\
\hline Daphnia & $34(4) \mathrm{e}$ & $33(11) e$ & $80(9) a b$ & $85(10) a$ & $84(19) a$ & 69(9)bc & $65(3) c$ & $50(19) \mathrm{d}$ \\
\hline Bosmina & $2(2) \mathrm{e}$ & $11(4) \mathrm{b}$ & $27(4) \mathrm{a}$ & $4(1) \mathrm{de}$ & $10(1) \mathrm{bc}$ & $11(2) b$ & $7(2) \mathrm{cd}$ & $4(3) \mathrm{de}$ \\
\hline Alona & $0(0) \mathrm{d}$ & $2(2) c$ & $5(2) a$ & $4(1) \mathrm{a}$ & $3(1) \mathrm{b}$ & $2(1) c$ & $1(1) \mathrm{cd}$ & $1(1) \mathrm{cd}$ \\
\hline Moina & $0(0) \mathrm{c}$ & $6(1) \mathrm{a}$ & $5(1) \mathrm{a}$ & $5(1) \mathrm{a}$ & $2(1) \mathrm{b}$ & $1(1) b$ & $0(0) \mathrm{c}$ & $0(0) c$ \\
\hline Pompholyx & $23(8) \mathrm{e}$ & $51(15) \mathrm{a}$ & $38(7) \mathrm{bcd}$ & $40(18) \mathrm{abc}$ & $47(7) \mathrm{ab}$ & 29 (14)de & $25(15) \mathrm{e}$ & $34(23) \mathrm{cde}$ \\
\hline Asplachana & $70(6) \mathrm{e}$ & $80(14) \mathrm{e}$ & $82(20) \mathrm{de}$ & 91(17)cde & $108(34) \mathrm{bc}$ & $119(32) \mathrm{ab}$ & 133(18)a & $104(13) \mathrm{bcd}$ \\
\hline Brachionus & $0(0) \mathrm{e}$ & $3(4) \mathrm{d}$ & $7(2) c$ & $11(2) b$ & $14(3) \mathrm{a}$ & $5(3) \mathrm{cd}$ & $0(0) \mathrm{e}$ & $0(0) \mathrm{e}$ \\
\hline \multicolumn{9}{|c|}{ Phytoplankton (ind./mL) } \\
\hline Synedra & $551(119) \mathrm{c}$ & $693(152) b c$ & $643(198) c$ & $1140(220) \mathrm{a}$ & $1019(213) \mathrm{a}$ & $804(240) \mathrm{b}$ & $414(214) \mathrm{d}$ & $315(169) d$ \\
\hline Fragilaria & $0(0) \mathrm{e}$ & 2(2)cde & 7(6)bcd & $20(13) a b$ & $34(8) a$ & $10(9) \mathrm{abc}$ & 1(1)de & $0(0) \mathrm{e}$ \\
\hline Cymbella & $80(34) a$ & $53(59) \mathrm{ab}$ & $40(13) \mathrm{ab}$ & $70(12) \mathrm{a}$ & $94(65) \mathrm{a}$ & $39(31) a b$ & $0(0) \mathrm{b}$ & $5(5) \mathrm{b}$ \\
\hline Anabaena, & $0(0) c$ & $13(11) c$ & $60(33) b c$ & $117(78) \mathrm{ab}$ & 144(47)a & 116(91)ab & $59(53) \mathrm{bc}$ & $21(37) \mathrm{c}$ \\
\hline Oscillatoria & $21(13) \mathrm{a}$ & $39(9) \mathrm{a}$ & $80(13) \mathrm{a}$ & $89(44) \mathrm{a}$ & $113(48) \mathrm{a}$ & $118(77) a$ & 129(101)a & $93(117) a$ \\
\hline Peridinium & $167(46) \mathrm{a}$ & $159(70) \mathrm{a}$ & $226(49) \mathrm{a}$ & $290(50) a$ & $328(127) a$ & $269(87) a$ & $253(60) a$ & $234(39) a$ \\
\hline
\end{tabular}

nutrients carried by the feeding streams, which, consequently, increase zooplanktons' food availability, increasing zooplanktons' abundance. In contrast, the cage culture at Site C likely decreases the amount of food materials for zooplanktons feeding on phytoplanktons, as well as the fishes feed on zoo- and phytoplankton reducing their numbers. Moreover, the concentration of nutrients was lower as we move further down in the reservoir, towards the cage culture area, which couples with lower abundance of both the phytoplankton and the zooplankton. The higher abundance of total planktons in the months of summer (June, July, August, and September) and the lower abundance in February and March (Figure 3), is mainly attributed to the temperature followed by lower primary production.

Planktons' population and their dynamic in aquatic systems are governed by complex interactions between biotic and abiotic factors. Among them, the physico-chemical condition of a water body is the major factor controlling species diver- 
Table 2. Eight months mean $( \pm S D)$ of zooplankton and phytoplankton's distribution in three different sampling locations in Kulekhani Reservoir, Nepal. Means in rows with common letters are not significantly different; $\mathrm{P}>0.05$.

\begin{tabular}{cccc}
\hline & Site A & Site B & Site C \\
\hline Zooplankton (ind./L) & & & \\
Nauplius & $66(21) \mathrm{a}$ & $58(20) \mathrm{a}$ & $44(16) \mathrm{b}$ \\
Daphnia & $73(22) \mathrm{a}$ & $63(24) \mathrm{b}$ & $53(20) \mathrm{c}$ \\
Bosmina & $11(8) \mathrm{a}$ & $10(9) \mathrm{a}$ & $7(7) \mathrm{b}$ \\
Alona & $3(2) \mathrm{a}$ & $2(2) \mathrm{b}$ & $2(2) \mathrm{b}$ \\
Pompholyx & $47(11) \mathrm{a}$ & $39(11) \mathrm{b}$ & $22(12) \mathrm{c}$ \\
Moina & $2(3) \mathrm{a}$ & $3(3) \mathrm{a}$ & $2(2) \mathrm{a}$ \\
Asplachana & $113(27) \mathrm{a}$ & $102(24) \mathrm{a}$ & $80(21) \mathrm{b}$ \\
Brachionus & $6(6) \mathrm{a}$ & $4(5) \mathrm{b}$ & $4(5) \mathrm{b}$ \\
Phytoplankton (ind./mL) & & $534(274) \mathrm{c}$ \\
Synedra & $852(284) \mathrm{a}$ & $707(323) \mathrm{b}$ & $133(103) \mathrm{b}$ \\
Fragilaria & $281(135) \mathrm{a}$ & $271(183) \mathrm{a}$ & $28(33) \mathrm{b}$ \\
Cymbella & $90(70) \mathrm{a}$ & $81(81) \mathrm{a}$ & $177(50) \mathrm{b}$ \\
Anabaena, & $266(51) \mathrm{a}$ & $279(97) \mathrm{a}$ & $56(43) \mathrm{a}$ \\
Oscillatoria & $102(84) \mathrm{a}$ & $98(63) \mathrm{a}$ & $176(50) \mathrm{a}$ \\
Peridinium & $266(84) \mathrm{a}$ & $279(97) \mathrm{a}$ &
\end{tabular}

sity of planktons [11]. The observed variation of planktons in the Kulekhani Reservoir was primarily due to the variations in temperature, availability of food, $\mathrm{DO}$ and $\mathrm{pH}$. For instances, temperature is a major determining factor in planktons' development and in controlling of zooplankton's hatching, growth and filtering rates. In general, zooplanktons have lower generation times, and their growth is delayed by low temperature compared to that of phytoplankton. The observed zooplanktons' diversity in the present study couples with the average surface water temperature of the reservoir, with a significant correlation coefficient $(\mathrm{R}=0.62)$. Similar, associations between temperature and zooplanktons have been previously reported in several water bodies [42] [43] [44]. In addition to the reservoir temperature, transparency, $\mathrm{pH}$ and alkalinity also showed positive correlation with the planktons' diversity and abundance in the reservoir water.

While $\mathrm{P}$ is considered as the prime nutrient that limits primary productivity in lakes and reservoirs [45] [46], numerous studies have shown that the biomass of phytoplanktons can be nitrogen-limited [39] [47]. The relatively higher concentrations of phosphate than nitrate, observed in the present study, indicates that the plankton's density in the reservoir was mainly the function of N. In general, inorganic forms of $\mathrm{N}$ and $\mathrm{P}$ were usually depleted in spring very rapidly and their concentrations remain at the low level till late autumn. Under such conditions, planktonic organisms can grow much more slowly than their maxi- 
mum growth rates, thus growth limitation can occur. This result can be supported by the low level of $\mathrm{N}$ in the months of February, March, May and June (Figure 2).

The population of the zooplanktons and phytoplanktons did not have peak at the same months; zooplanktons were highest in October while phytoplanktons were highest in July (Figure 3). The low population of the phytoplanktons in September and October when there was higher population of the zooplanktons might be due to depletion of the nutrients, low light penetration due to low transparency, and grazing by zooplanktons and fishes. It is well known that density of zooplankton controls the phytoplankton's biomass as the zooplankton grazing is a strong modulator of phytoplankton in lakes and reservoirs [48] [49]. Thus, the higher population of the zooplanktons could have reduced the population of the phytoplanktons in September and October.

All factors described above might be of secondary importance on planktons' biomass in the reservoir, if considerable plankton standing crop is removed by flushing [50]. If plankton community structure is affected by such flushing and thus residence time of water in the reservoir, we expect that both phytoplankton and zooplankton biomass will decrease during periods of high water discharge and that plankton species with high generation time will be replaced during flooding periods by species with shorter generation time [51] [52]. But this effect seemed to be less important in the Kulekhani Reservoir, because it was made for hydropower generation and flushing is done from the bottom which probably does not affect the planktons residing on the surface.

\subsection{Shannon-Wiener Diversity Indexes}

Shannon-Wiener index values for zooplankton were highest at Site A, followed by Site B and then Site C during the study period, however, it remained similar among the sites for phytoplankton (Figure 5). Shannon-Wiener index for both zooplankton and phytoplankton were relatively lower earlier in the season followed by a slight increase in May then remained similar through September (Figure 5). While its interpretation remained controversial in term of scale of pollution, the Shannon-Wiener diversity index has been used as a suitable indicator for water quality [53] [54]. The Shannon-Wiener diversity index values measured in this study for both zooplankton (1.03 - 2.09) and phytoplankton (1.40 - 2.01) indicate that the Kulekhani Reservoir water as moderately polluted water body [55] [56]. The observed general pattern of low pollutants with decrease in values for the zooplankton and phytoplankton diversity as we move downstream form Site A to Site C is similar to previously reported trends [57]. However, this diversity index greatly varies from study to another study, which makes it very difficult to make comparison among the studies and draw a common conclusion because of environmental variabilities among the studies [58].

\subsection{Principle Component Analysis (PCA)}

Principal component analysis (PCA) was performed on correlation matrix on 

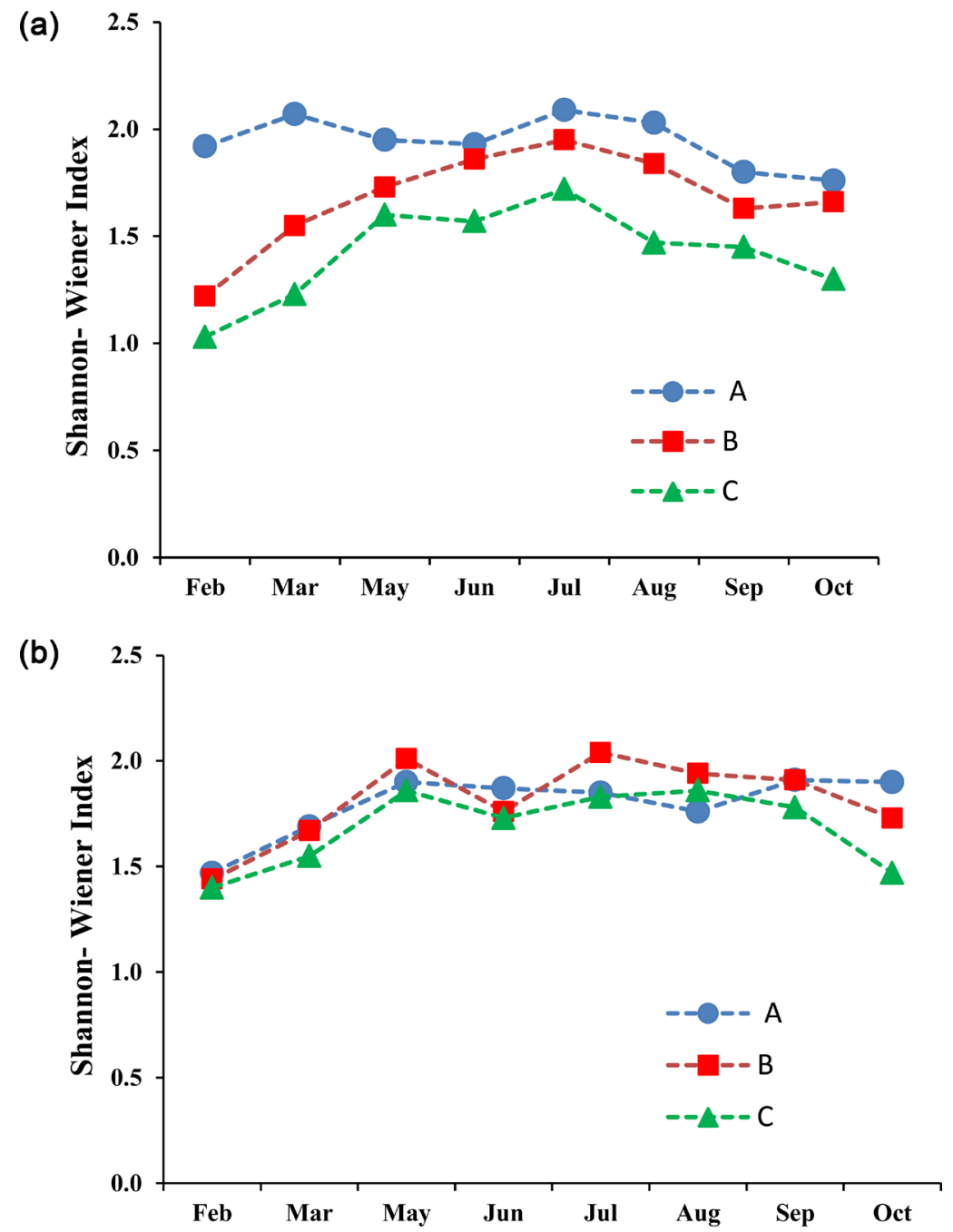

Figure 5. Shannon-Wiener Diversity Index for Zooplankton (a) and Phytoplankton (b) in Kulekhani Reservoir, Nepal. The Blue circles, Red squares and Green triangles represent study sites, Site A, Site B, and Site C, respectively.

nine environmental and biological variables and showed that the first and second principle components (PCs) respectively explained $34.64 \%$ and $20.52 \%$ of the variability in the data (Figure 6(a)). Given the foregoing component coefficients, the first PC appears to be essentially a weighted difference between transparence, temperature, total zooplankton, total phytoplankton, $\mathrm{pH}$, and $\mathrm{CO}_{2}$. Moreover, the second PC appears to be the sum of nitrate, $\mathrm{CO}_{2}$, alkanility, total hardness, phosphate, total zooplankton and total phytoplankton. It was also noticed that the total zooplankton and phytoplankton strongly positively correlated with nitrate and phosphate, and negatively correlated with transparency (Figure 6(a)). Similarly, total zooplanktons were highly positively correlated with total phytoplanktons (Figure 6(a)). The PCA biplot for sites and samples distinguished the environmental and biological difference among sites and samples (Figure 6(b)). As a whole, Site A was clearly identified by being fresher and richer in nutrients (phosphate and nitrate), low transparency, high zooplankton 
(a)

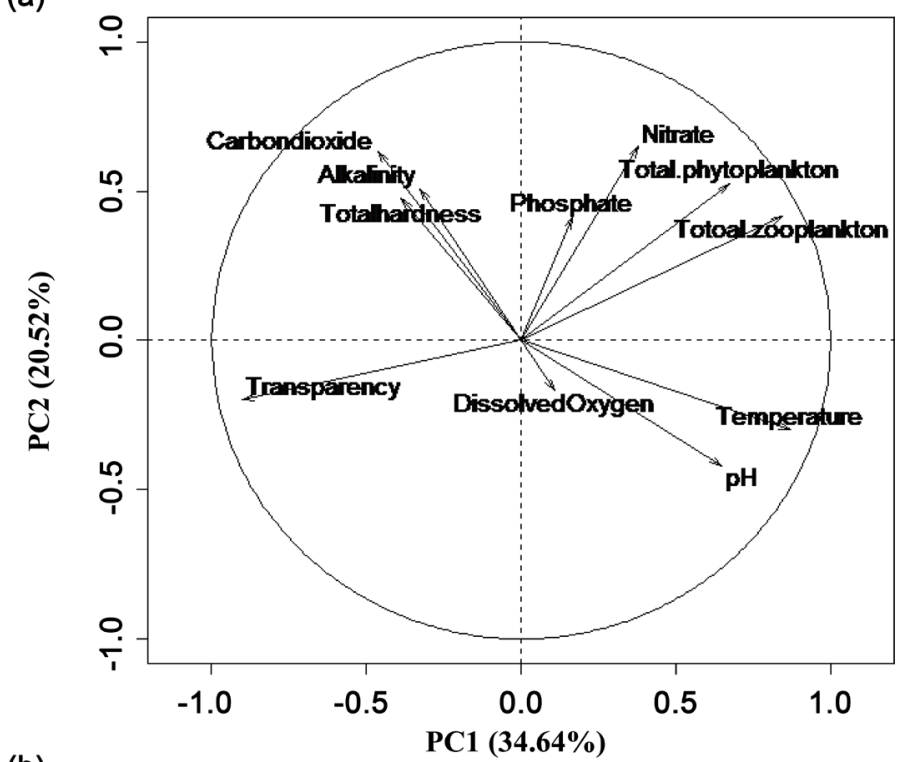

(b)

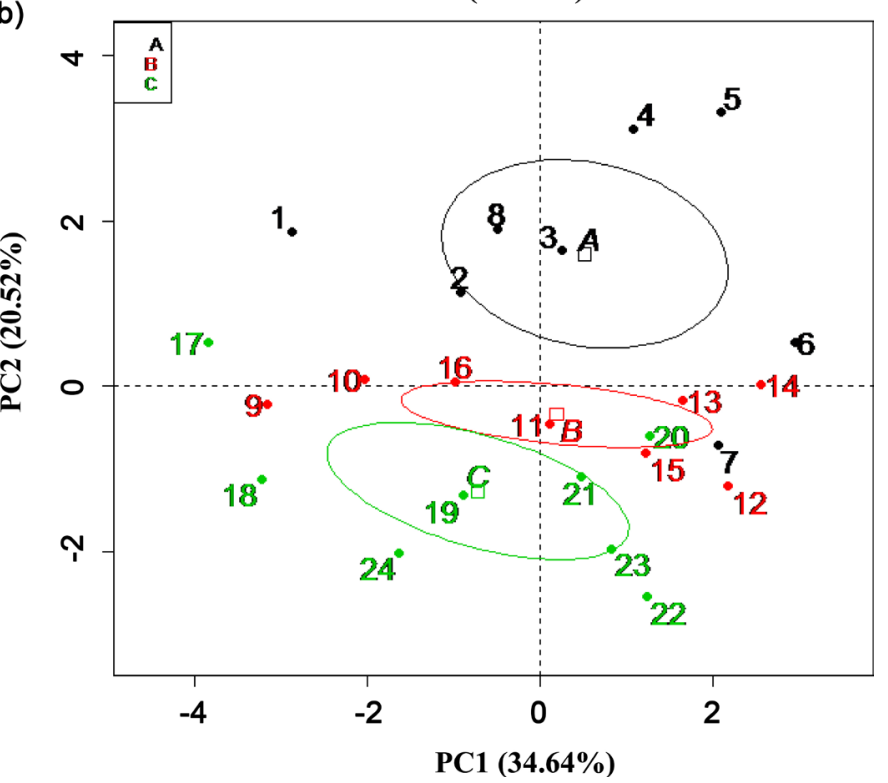

Figure 6. PCA biplot for environmental and biological variables (a) and PCA biplot for sites and samples (b) for the water quality and planktons in the Kulekhani Multipurpose Reservoir, Nepal.

and phytoplankton density. The water quality and biological community in Site B differed than those in the Site A and Site C. Site B was categorized by medium nutrients, medium transparency, medium zooplankton and phytoplankton density, and Site $\mathrm{C}$ was characterized by lower nutrients, higher water transparency, low zooplankton and phytoplankton density. High absolute correlation values between PCs and the original variables, also referred as the loading of the variables on PCs, are useful to identify which parameters accounted for most variation in the data set [59]. PCA results in this study indicated that physicalchemical factors transparence, temperature, $\mathrm{pH}, \mathrm{CO}_{2}$, nitrate and phosphate played important role in overall environmental variation. As identified by PCA 
for zooplankton community, zooplankton genera Cyclops, Daphnia, Alona, Brachionus, Moina, Keratella, Polyuanthra, Asplachana, and Nauplius have greatest contributions to the variation of the zooplankton community. Similarly, Synedra, Melosira, Fragilaria, Amphora, Anabaena, Peridinium, Oscillatoria and Scendesmus played an important role in the variation of phytoplankton community composition (Figure 6).

\subsection{Canonical Correlation Analysis (CCA)}

The canonical correlation analysis (CCA) between environmental variables and zooplankton showed that two pairs of significant canonical variables, with correlations of 0.98 and 0.97 , which explained $77.9 \%$ of the variation (Table S7). The CCA showed strong association of environmental variables (transparency, DO, temperature, and $\mathrm{CO}_{2}$ ) with select zooplankton genera (Cyclops, Moina, and Polyanthra), and Nauplius. In contrast, one pair of canonical variable between environmental variables and phytoplankton, with correlation of 0.99 , accounted for $77.5 \%$ of the variation. Strong positive correlations were observed for select environmental variables (DO and alkalinity) with select phytoplankton genera (Melosira, Anabaena, and Scendesmus) (Table S7).

The significant canonical correlation between water quality and planktons, and between zooplankton and phytoplankton suggest that planktons' distribution is strongly associated with reservoir water quality and other planktonic community in the reservoir [11]. The high correlation between the planktons and temperature can be described as the effect of temperature on growth and development of planktons. The negative correlation between transparency and planktons in this study indicates decrease in light penetration capacity and transparency with higher density of planktons in the reservoir. Moreover, a light limitation is expected to prevail for phytoplanktons [60]. Thus, these phytoplanktons can be limited either by the ability to convert excess nutrients into biomass or by growth rate [61] which is probably the reason for the rapid and irregular fluctuation of planktons in the reservoir. In addition, nitrate and phosphate are major limiting nutrients for the growths of phytoplankton, and ultimately the growth of zooplankton. The results also showed that, inorganic of $\mathrm{N}$ and $\mathrm{P}$ were very rapidly depleted in spring and their concentrations remain at low levels till until late autumn. Such variation in nutrient concentrations and unfavorable temperature were probably the reasons for lower planktons' abundance in February, March, and October (Table 2, Figure 3 and Figure 4).

The population of the phytoplankton is dependent upon the population of the zooplankton, as zooplankton grazing was identified as a strong modulator of the phytoplankton yield in lakes and reservoirs [62]. The results from the present study showed a pattern of low or inverse correlation between phytoplankton and zooplankton population density. It has been previously reported that the grazing effect of the herbivorous zooplankton is sufficient to limit the phytoplankton population in time as well as in quantity. However, some studies suggest that 
zooplankton avoid living in the area with dense phytoplankton, may be due to unfavorable chemical condition produced by phytoplankton populations' i.e. exclusion by phytoplankton [63]. While a strong correlation between zooplankton and phytoplankton was observed in this study, whether such relationship was due to grazing or unfavorable chemicals remains to be tested.

\section{Conclusion}

The investigation of water quality and planktons' community composition showed that the Kulekhani Multipurpose Reservoir is low to moderately polluted, and the water is suitable for the growth and development of aquatic organisms as well as for the fish culture. Unlike many other aquatic systems, the concentration of phosphate was found to be relatively higher in comparison to the levels of nitrate in the reservoir which suggests that the reservoir water is potentially nitrogen limited. The eleven genera of zooplanktons (three groups) and twelve genera of phytoplankton (four classes) were collected and identified in the reservoir water. Among the eleven genera of the zooplanktons, Cyclops was the most dominant with $25 \%$ contribution from all three sites which were followed by Asplanchana (19.94\%) and Keratella (13.17\%) while Filina (0.025\%) was least abundant followed by Alona (0.45). Similarly, among the 12 genera, Synedra (34.85\%) was most dominant phytoplankton followed by Melosira (24.56\%), and Fragilaria (0.475\%) was the rarest genera followed by Amphora (1.09\%). Among the three study sites, Site A was the richest site having maximum percentage of both zooplankton and phytoplanktons, followed by Site B and Site $\mathrm{C}$ at the last. During the investigation period, population density of the planktons varied in relation to the fluctuation of the physico-chemical parameters. Zooplanktons showed positive correlation with temperature, $\mathrm{pH}$, nitrate and phytoplankton while they showed negative correlation with transparency, DO, hardness and phosphate. Similarly, phytoplankton showed positive correlation with temperature, $\mathrm{pH}, \mathrm{DO}$, alkalinity and nitrate but showed negative correlation with transparency, hardness and orthophosphate. While a select groups of zooplanktons (Cyclops, Keratella, and Polyanthra), and phytoplankton (Navicula, Melosira, Amphora, Chroococcus and Staurastrum) showed significantly interaction between sites and seasons, the abundance of other planktons varied either with the season or among the sampling sites. These results showed that seasonal water level fluctuations, along with variation of select water quality parameters, affect the abundance and distribution of planktons in the reservoir. Such changes can negatively impact the food for the fish in the cage culture, affecting the livelihood of the people extensively relying on these fish farming.

\section{Acknowledgements}

We are thankful to the Central Department of Environmental Science, Tribhuvan University, Kirtipur for providing laboratory facilities. Special thanks to Dr. Jeewan Shrestha for her guidance to complete this project. We would also like to 
thank Mr. Tej B. Saund, Mr. Dhruba Pokharel, and Dr. Umakant R. Yadav for their valuable guidance and support during the course of this study.

\section{References}

[1] Kayastha, P., Dhital, M.R. and De Smedt, F. (2013) Evaluation and Comparison of GIS Based Landslide Susceptibility Mapping Procedures in Kulekhani Watershed, Nepal. Journal of the Geological Society of India, 81, 219-231. https://doi.org/10.1007/s12594-013-0025-7

[2] Shrestha, S., Khatiwada, M., Babel, M.S. and Parajuli, K. (2014) Impact of Climate Change on River Flow and Hydropower Production in Kulekhani Hydropower Project of Nepal. Environmental Processes, 1, 231-250.

https://doi.org/10.1007/s40710-014-0020-Z

[3] Karky, B. and Joshi, S.L. (2009) Payment for Environmental Services: An Approach to Enhancing Water Storage Capacity. Sustainable Mountain Development, 56, 27-30.

[4] K.C, B. (2004) A Hydro-Meteorological Study of Kulekhani Watershed. CDHM-Tribhuvan University, Kathmandu.

[5] NEA (Nepal Electricity Authority) (2009) Annual Report, A Year in Review-Fiscal Year 2008/2009. Durbar Marg, Kathmandu.

[6] Gurung, T.B., Mulmi, R.M., Kalyan, K.C., Wagle, G., Pradhan, G.B., Upadhayaya, K. and Rai, A.K. (2010) Cage Fish Culture: An Alternative Livelihood Option for Communities Displaced by Reservoir Impoundment in Kulekhani, Nepal. In: De Silva, S.S. and Davy F.B., Eds., Success Stories in Asian Aquaculture, Springer, Berlin, 85-102. https://doi.org/10.1007/978-90-481-3087-0 5

[7] Koirala, S. (2016) Hydropower Induced Displacement in Nepal. PhD Dissertation, University of Otago.

[8] Sharma, R.H. and Awal, R. (2013) Hydropower Development in Nepal. Renewable and Sustainable Energy Reviews, 21, 684-693.

[9] Sangroula, D.P. (2009) Hydropower Development and Its Sustainability with Respect to Sedimentation in Nepal. Journal of the Institute of Engineering, 7, 1-9. https://doi.org/10.3126/jie.v7i1.2063

[10] Shrestha, M.K., Pandit, N.P., Bista, J.D., Wagle, S.K., Dahal, S.P. and Kc, K. (2009) Water Quality Pattern and Natural Food-Based Cage Aquaculture in Kulehani Reservoir. In: Shrestha, M.K. and Pant, J., Eds., Small-Scale Aquaculture for Rural Livelihoods, Tribhuvan University, Nepal, 118-125.

[11] Heegaard, E., Birkash, H., Gibsion, C.E., Smith, S.J. and Wolfe-Murphy, S. (2001) Species Environmental Relationships of Aquatic Macrophytes in Northern Ireland. Aquatic Botany, 70, 75-223.

[12] Saund, T.B. and Shrestha, J. (2007) Fish and Benthic Fauna in Kulekhani Reservoir, Makwanpur. Nepal Journal of Science and Technology, 8, 63-68.

[13] Bokan, L.T. (2015) Simulation of Sediment Yield Using SWAT Model: A Case of Kulekhani Watershed. M.S. Dissertation Norwegian University of Science and Technology, Trondheim.

[14] Nippon Koei Co. Ltd. (1994) Master Plan Study on Sediment Control for Kulekhani Watershed. Kulekhani Disaster Prevention Project, Stage III-Phase III, Main Report. Nepal Electricity Authority/Nippon Koei Co. LTD, Consulting Engineers, Tokyo.

[15] Sthapit, K.M. (1995) Sedimentation of Lakes and Reservoirs with Special Reference to the Kulekhani Reservoir. In: Schreier, H., Shah, P.B. and Brown, S., Eds., Chal- 
lenges in Mountain Resource Management-Processes, Trends and Dynamics in Middle Mountain Watersheds, Proceedings of a Workshop Held in Kathmandu, Nepal, 5-12.

[16] Shah, P.B. (1996) Water Dynamics and Population Pressure in the Nepalese Himalaya. GeoJournal, 40, 45-51.

[17] Shrestha, R.S. (2010) Electricity Crisis (Load Shedding) in Nepal, Its Manifestations and Ramifications. Hydro Nepal: Journal of Water, Energy and Environment, 6, 7-17.

[18] Wu, J., Huang, J., Han, X., Gao, X., He, F., Jiang, M., Jiang, Z., Primack, R.B. and Shen, Z. (2004) The Three Gorges Dam: An Ecological Perspective. Frontiers in Ecology and the Environment, 2, 241-248. https://doi.org/10.1890/1540-9295(2004)002[0241:TTGDAE]2.0.CO;2

[19] Yadav, A.M. (1989) Effect of Spentwash (Distillery Effluent) on Properties of Soils and Composition of Leachate. M.S. Dissertation, Mahatama Phule Agricultural University, Rahuri.

[20] Rai, A.K. (1990) Annual Progress Report: Inland Fisheries Project, Indrasarobar, Kulekhani, Nepal. Fisheries Development Division.

[21] Integrated Watershed Management Plan (IWMP) (1992) Integrated Watershed Management Plan for Kulekhani Watershed, Integrated Watershed Management Project, Phewa Tal and Kulekhani Watersheds, Department of Soil Conservation. Babar Mahal, Kathmandu.

[22] Central Bureau of Statistics (CBS) (2003) Population Monograph of Nepal. CBS, HMG/Nepal, Kathmandu.

[23] APHA (American Public Health Association), American Water Works Association, and the Water Pollution Control Federation (2005) Standard Methods for the Examination of Water and Wastewater. 21st Edition, APHA, Washington DC.

[24] Niraula, R. (2012) Evaluation of the Limnological Status of Beeshazar Lake, a Ramsar Site in Central Nepal. Journal of Water Resource and Protection, 4, 256-263. https://doi.org/10.4236/jwarp.2012.45028

[25] Shrestha, S. and Adhikari, P.L. (2016) Investigating Temporal Variation of Water Quality and Benthic Macroinvertebrates in Taudaha Lake, Kathmandu, Nepal. Journal of Water Resource and Protection, 8, 1283-1296.

https://doi.org/10.4236/jwarp.2016.813098

[26] Welch, P.S. (1948) Limnological Methods. McGraw-Hill Inc.

[27] Edmondson, W.T. (1959) Fresh Water Biology. 2nd Edition, John Wiley and Sons Inc., New York.

[28] Needham, J.G. and Needham, R.R. (1962) A Guide to Fresh Water Biology. Holdenday Inc., San Francisco.

[29] Shannon, C.E. and Weaver, W. (1949) The Mathematical Theory of Communication. University of Illinois Press, Urbana.

[30] Kuehl, R.O. and Kuehl, R.O. (2000) Design of Experiments: Statistical Principles of Research Design and Analysis. Pacific Grove, Duxbury/Thomson Learning, 469-472.

[31] Kannan, V. and Job, S.V. (1980) Diurnal Depth-Wise and Seasonal Changes of Physico-Chemical Factors in Sathiar Reservoir. Hydrobiologia, 70, 103-117. https://doi.org/10.1007/BF00015496

[32] Swingle, H.S. (1967) Standardization of Chemical Analysis for Water and Pond Muds. FAO Fisheries Report, 4, 397-421. 
[33] Ward, P.R.B. (1982) Physical Limnology. In: Thornton, J.A., Ed., Lake McIlwaine: The Eutrophication and Recovery of a Tropical African Man-Made Lake, Monographiae Biologicae, The Hague. https://doi.org/10.1007/978-94-009-7983-3 3

[34] Cole, G.A. (1975) Textbook of Limnology. The C. C. Mosby Co., St Louis.

[35] Sugunan, V.V. (1995) Reservoir Fisheries of India. FAO Fisheries Technical Paper 345 , Rome.

[36] Sousa, W., Attayde, J.L., Rocha, E.D.S. and Eskinazi-Sant'Anna, E.M. (2008) The Response of Zooplankton Assemblages to Variations in the Water Quality of Four Man-Made Lakes in Semi-Arid Northeastern Brazil. Journal of Plankton Research, 30, 699-708. https://doi.org/10.1093/plankt/fbn032

[37] Adhikari, P.L., White, J.R., Maiti, K. and Nguyen, N. (2015) Phosphorus Speciation and Sedimentary Phosphorus Release from the Gulf of Mexico Sediments: Implication for Hypoxia. Estuarine, Coastal and Shelf Science, 164, 77-85.

[38] Diaz, M.M. and Pedrozo, F.L. (1996) Nutrient Limitation in Andean-Patagonian Lakes at Latitude 40-41 S. Archiv für Hydrobiologie, 138, 123-143.

[39] Jansson, M., Blomqvist, P., Jonsson, A. and BergstrÖm, A.K. (1996) Nutrient Limitation of Bacterioplankton, Autotrophic and Mixotrophic Phytoplankton, and Heterotrophic Nanoflagellates in Lake Örträsket. Limnology and Oceanography, 41, 1552-1559. https://doi.org/10.4319/lo.1996.41.7.1552

[40] Sreenivasan, A. (1965) Limnology of Tropical Impoundments. Hydrobiologia, 26, 501-516. https://doi.org/10.1007/BF00045541

[41] Shrestha, S., Farrelly, J., Eggleton, M. and Chen, Y. (2017) Effects of Conservation Wetlands on Stream Habitat, Water Quality and Fish Communities in Agricultural Watershed of the Lower Mississippi River Basin. Ecological Engineering, 107, 99-109.

[42] George, D.G., Hewitt, D.P., Lund, J.W.G. and Smyly, W.J.P. (1990) The Relative Effects of Enrichment and Climatic Change on the Long-Term Dynamics of Daphnia in Esthwaite Water, Cumbria. Freshwater Biology, 13, 55-70.

https://doi.org/10.1111/j.1365-2427.1990.tb00253.x

[43] Morales-Baquero, R., Carrillo, P. and Cruz-Pizarro, L. (1995) Effects of Fluctuating Temperatures on the Population Dynamics of Hexarthra bulgarica (Wiszniewski) from High Mountain Lakes in Sierra Nevada (Spain). Hydrobiologia, 313-314, 359-363. https://doi.org/10.1007/BF00025970

[44] Straile, D. (2000) Meteorological Forcing of Plankton Dynamics in a Large and Deep Continental European Lake. Oecologia, 122, 44-50.

https://doi.org/10.1007/PL00008834

[45] Vollenweider, R.A. (1968) Scientific Fundamentals of the Eutrophication of Lakes and Flowing Waters, with Particular Reference to Nitrogen and Phosphorous as Factors in Eutrophication. Organization for Economic Co-Operation and Development. Directorate for Scientific Affairs, Paris.

[46] Vollenweider, R. (1976) Advances in Defining Critical Loading Levels for Phosphorus in Lake Eutrophication. Memorie dell Istituto Italiano di Idrobiologia, 33, 53-83.

[47] Moss, B., McGowan, S. and Carvalho, L. (1994) Determination of Phytoplankton Crops by Top-Down and Bottom-Up Mechanisms in a Group of English Lakes, the West Midland Meres. Limnology and Oceanography, 39, 1020-1029. https://doi.org/10.4319/1o.1994.39.5.1020

[48] Vanni, M.J. (1987) Effects of Nutrients and Zooplankton Size on the Structure of a Phytoplankton Community. Ecology, 68, 624-635. https://doi.org/10.2307/1938467 
[49] Dawidowicz, P. (1990) Effectiveness of Phytoplankton Control by Large-Bodied and Small-Bodied Zooplankton. Hydrobiologia, 200, 43-47. https://doi.org/10.1007/BF02530327

[50] Dickman, M. (1969) Some Effects of Lake Renewal on Phytoplankton Productivity and Species Composition. Limnology and Oceanography, 14, 70-76. https://doi.org/10.4319/lo.1969.14.5.0660

[51] Baranyi, C., Hein, T., Holarek, C., Keckeis, S. and Schiemer, F. (2002) Zooplankton Biomass and Community Structure in a Danube River Floodplain System: Effects of Hydrology. Freshwater Biology, 47, 473-482. https://doi.org/10.1046/j.1365-2427.2002.00822.x

[52] Olding, D.D., Hellebust, J.A. and Douglas, M.S.V. (2000) Phytoplankton Community Composition in Relation to Water Quality and Water-Body Morphometry in Urban Lakes, Reservoirs, and Ponds. Canadian Journal of Fisheries and Aquatic Sciences, 57, 2163-2174. https://doi.org/10.1139/f00-176

[53] Balloch, D., Davies, C.E. and Jones, F.H. (1976) Biological Assessment of Water Quality in Three British Rivers: The North Esk (Scotland), the Ivel (England) and the Taf (Wales) Water Pollution Control, U.K.

[54] Gao, X. and Song, J. (2005) Phytoplankton Distributions and Their Relationship with the Environment in the Changjiang Estuary, China. Marine Pollution Bulletin, 50, 327-335.

[55] Hendley, N.I. (1977) The Species Diversity Index of Some In-Shore Diatoms Communities and Its Use in Assessing the Degree of Pollution Insult on Parts of the North Coast of Cornwall. In: Cramme, J., Ed., 4th Symposium on Recent and Fossil Marine Diatoms, Oslo Vaduz, 355-378.

[56] Khan, A., Kamal, D., Mahmud, M.M., Rahman, M.A. and Hossain, M.A. (2007) Diversity, Distribution and Abundance of Benthos in Mouri River, Khulna, Bangladesh. International Journal of Sustainable Crop Production, 2, 19-23.

[57] Ogbeibu, A.E. and Orbhabor, B.J. (2002) Ecological Impact of River Impoundment using Benthic Macro-Invertebrates as Indicators. Water Research, 36, 2427-2436.

[58] Rojo, C. and Cobelas, M.A. (1993) Hypertrophic Phytoplankton and the Intermediate Disturbance Hypothesis. Hydrobiologia, 249, 43-57. https://doi.org/10.1007/BF00008842

[59] Ramette, A. (2007) Multivariate Analyses in Microbial Ecology. FEMS Microbiology Ecology, 62, 142-160. https://doi.org/10.1111/j.1574-6941.2007.00375.x

[60] Noges, P., Noges, T., Laugaste, R., Haberman, J. and Kisand, V. (1997) Tendencies and Relationships in the Pelagic Environment and Plankton Community of Lake Vorsjarv in 1964-93. Proceedings of the Estonian Academy of Sciences, Biology and Ecology, 46, 40-57.

[61] Thingstad, T.F., Zweifel, U.L. and Rassoulzadegan, F. (1998) P Limitation of Heterotrophic Bacteria and Phytoplankton in the Northwest Mediterranean. Limnology and Oceanography, 43, 88-94. https://doi.org/10.4319/lo.1998.43.1.0088

[62] Shapiro, J. (1980) The Importance of Trophic-Level Interactions to the Abundance and Species Composition of Algae in Lakes. In: Barica, J. and Muir, L.R., Eds., Hypertrophic Ecosystems, The Hague, 105-116. https://doi.org/10.1007/978-94-009-9203-0 12

[63] Anderson, G.C., Comita, G.W. and Engstrom-Heg, V. (1955) A Note on the Phytoplankton-Zooplankton Relationships in Two Lakes in Washington. Ecological Society of America, 36, 757-759. https://doi.org/10.2307/1931314 


\section{Appendix A. Supplementary Data}

Table S1. Two-way repeated measure ANOVAs with Tukey's 1 degree-of freedom test for nonadditivity and the effect of month and site on the values of water quality variables Kulekhani Multipurpose Reservoir, Nepal.

\begin{tabular}{|c|c|c|c|c|c|c|}
\hline & \multicolumn{2}{|c|}{ Month } & \multicolumn{2}{|c|}{ Site } & \multicolumn{2}{|c|}{ Month x Site } \\
\hline & $\mathrm{F}$ & $\mathrm{P}$ & $\mathrm{F}$ & $\mathrm{P}$ & $\mathrm{F}$ & $\mathrm{P}$ \\
\hline Temperature & 31.3 & $<0.0001$ & 1.71 & 0.217 & 4.11 & 0.064 \\
\hline Transparency & 0.16 & 0.204 & 5.83 & 0.016 & 6.59 & 0.023 \\
\hline $\mathrm{pH}$ & 8.55 & 0.0004 & 1.43 & 0.272 & 1.73 & 0.212 \\
\hline $\mathrm{DO}$ & 23.67 & $<0.0001$ & 0.91 & 0.426 & 0.48 & 0.500 \\
\hline $\mathrm{CO}_{2}$ & 2.78 & 0.0493 & 2.20 & 0.149 & 2.62 & 0.129 \\
\hline Alkalinity & 1.55 & 0.235 & 3.85 & 0.049 & 15.30 & 0.0018 \\
\hline Total hardness & 2.63 & 0.058 & 3.59 & 0.056 & 1.36 & 0.265 \\
\hline Nitrate & 1.39 & 0.284 & 7.79 & 0.005 & 0 & 0.980 \\
\hline Phosphate & 0.46 & 0.849 & 6.07 & 0.013 & 0.38 & 0.549 \\
\hline
\end{tabular}

Table S2. Monthly mean (SD) water quality variables in the Kulekhani Multipurpose Reservoir, Nepal. Means in rows with common letters are not significantly different; $P>0.05$.

\begin{tabular}{ccccccccc}
\hline Variables & Feb & Mar & May & Jun & Jul & Aug & Sep & Oct \\
\hline Temperature & $13.90(0.60) \mathrm{d}$ & $14.93(0.85) \mathrm{d}$ & $20.77(1.17) \mathrm{bc}$ & $24.10(1.51) \mathrm{a}$ & $22.40(0.66) \mathrm{ab}$ & $23.50(1.32) \mathrm{a}$ & $22.46(1.67) \mathrm{ab}$ & $19.50(1.65) \mathrm{c}$ \\
$\mathrm{DO}$ & $9.15(1.00) \mathrm{b}$ & $9.97(0.61) \mathrm{b}$ & $9.30(0.70) \mathrm{b}$ & $8.05(.28) \mathrm{c}$ & $7.45(0.05) \mathrm{c}$ & $10.93(0.21) \mathrm{a}$ & $9.57(0.25) \mathrm{b}$ & $6.47(0.21) \mathrm{d}$ \\
$\mathrm{pH}$ & $7.98(0.60) \mathrm{d}$ & $8.65(0.09) \mathrm{bc}$ & $8.96(0.15) \mathrm{ab}$ & $9.10(0.44) \mathrm{ab}$ & $8.41(0.18) \mathrm{cd}$ & $9.38(0.08) \mathrm{a}$ & $9.10(0.10) \mathrm{ab}$ & $8.38(0.13) \mathrm{cd}$ \\
$\mathrm{CO}_{2}$ & $0.80(0.10) \mathrm{a}$ & $0.45(0.13) \mathrm{ab}$ & $0.18(0.03) \mathrm{b}$ & $0.23(0.15) \mathrm{b}$ & $0.45(0.56) \mathrm{ab}$ & $0.20(0.17) \mathrm{b}$ & $0.15(0.13) \mathrm{b}$ & $0.47(0.25) \mathrm{ab}$ \\
\hline
\end{tabular}

Table S3. Mean (SD) of water quality variables Nitrate and Phosphate at three sampling sites, Kulekhani Multipurpose Reservoir, Nepal. Means in rows with common letters are not significantly different; $P>0.05$.

\begin{tabular}{cccc}
\hline Variables & Site A & Site B & Site C \\
\hline Nitrate $(\mathrm{mg} / \mathrm{L})$ & $0.13(0.04) \mathrm{a}$ & $0.08(0.05) \mathrm{b}$ & $0.06(0.02) \mathrm{b}$ \\
Phosphate $(\mathrm{mg} / \mathrm{L})$ & $0.22(0.03) \mathrm{a}$ & $0.15(0.03) \mathrm{b}$ & $0.18(0.05) \mathrm{b}$ \\
\hline
\end{tabular}

Table S4. List of all the zooplankton's and phytoplanktons identified and quantified in this study.

\begin{tabular}{ccc}
\hline Planktons & Group/Class & Genera \\
\hline Zooplanktons & Copepoda & Cyclops \\
& & Nauplius \\
& & Daphnia \\
& Cladocera & Bosmina \\
& & Alona \\
& & Moina \\
\hline
\end{tabular}




\section{Continued}

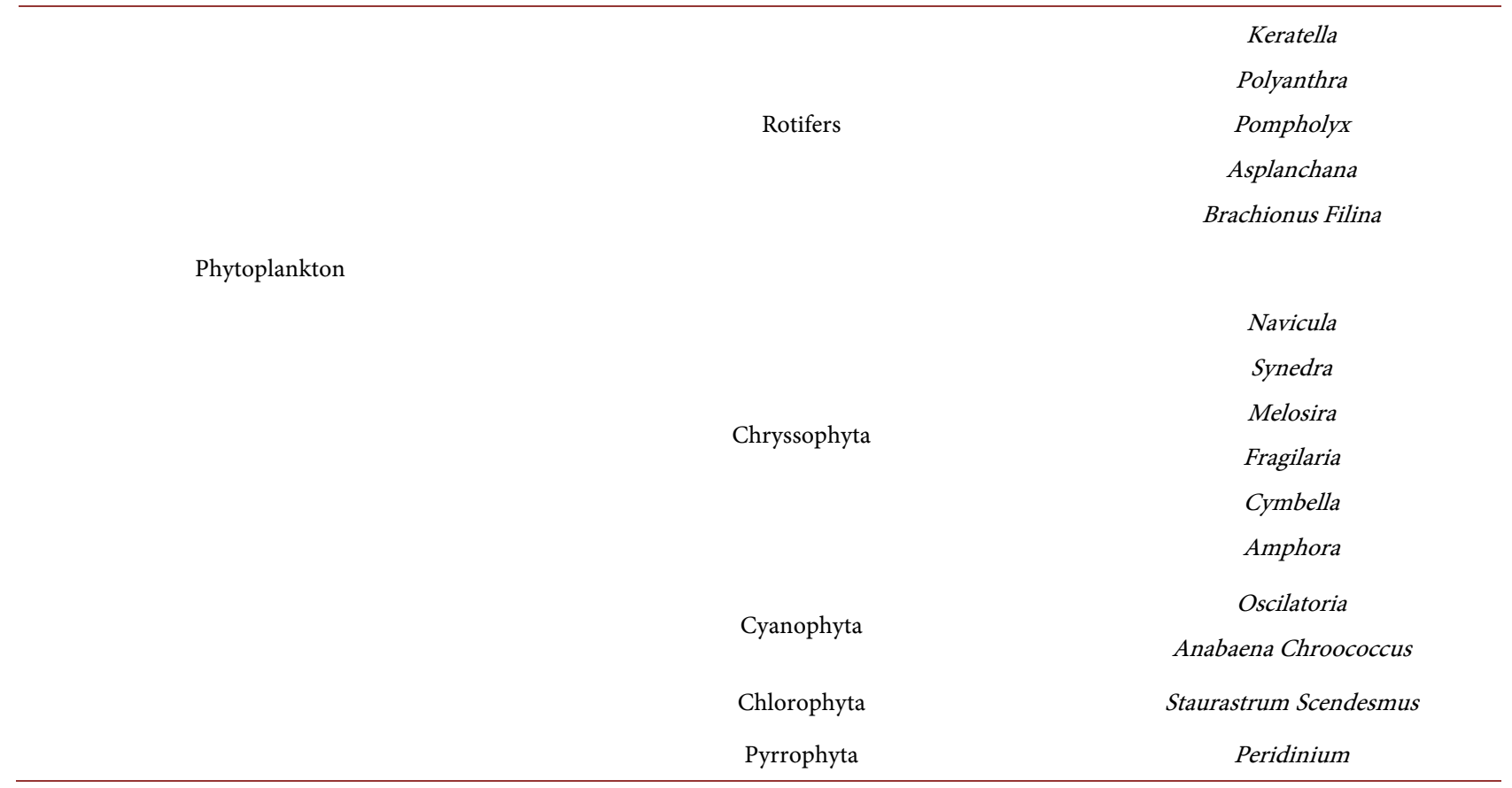

Table S5. Two-way repeated measure ANOVAs with Tukey's 1 degree-of freedom test for nonadditivity and the effect of month and site on the values of zooplankton in the Kulekhani Multipurpose Reservoir, Nepal.

\begin{tabular}{|c|c|c|c|c|c|c|}
\hline \multirow{2}{*}{ Group/Genera } & \multicolumn{2}{|c|}{ Sites } & \multicolumn{2}{|c|}{ Months } & \multicolumn{2}{|c|}{ Months $\times$ Sites } \\
\hline & $\mathrm{F}$ & $P$ & $\mathrm{~F}$ & $\mathrm{P}$ & $\mathrm{F}$ & $\mathrm{P}$ \\
\hline Copepoda & 0.76 & 0.63 & 0.06 & 0.94 & 4.98 & 0.0439 \\
\hline Cyclops & 0.75 & 0.635 & 0.04 & 0.966 & 5.00 & 0.0435 \\
\hline Nauplius & 12.46 & $<0.0001$ & 11.71 & 0.001 & 2.52 & 0.137 \\
\hline Cladocera & 39.89 & $<0.0001$ & 24.12 & $<0.0001$ & 0.13 & 0.72 \\
\hline Daphnia & 18.55 & $<0.0001$ & 15.03 & 0.0003 & 0.01 & 0.936 \\
\hline Bosmina & 60.95 & $<0.0001$ & 11.59 & 0.001 & 3.64 & 0.078 \\
\hline Rotifers & 0.87 & 0.56 & 2.18 & 0.15 & 22.56 & 0.0004 \\
\hline Alona & 20.89 & $<0.0001$ & 9.59 & 0.002 & 1.88 & 0.194 \\
\hline Moina & 164.6 & $<0.0001$ & 0.30 & 0.746 & 0 & 0.998 \\
\hline Keratella & 0.86 & 0.564 & 1.55 & 0.249 & 17.43 & 0.001 \\
\hline Polyanthra & 1.59 & 0.224 & 2.56 & 0.116 & 18.64 & 0.0008 \\
\hline Pompholyx & 7.79 & 0.0006 & 34.85 & $<0.0001$ & 0.01 & 0.942 \\
\hline Asplachana & 7.55 & 0.0007 & 12.63 & 0.0007 & 0.47 & 0.505 \\
\hline Brachionus & 32.28 & $<0.0001$ & 5.17 & 0.021 & 3.08 & 0.103 \\
\hline Total zooplankton & 0.75 & 0.639 & 0.32 & 0.732 & 10.94 & 0.0057 \\
\hline
\end{tabular}


Table S6. Two-way repeated measure ANOVAs with Tukey's 1 degree-of freedom test for nonadditivity and the effect of month and site on the values of phytoplankton in the Kulekhani Multipurpose Reservoir, Nepal.

\begin{tabular}{|c|c|c|c|c|c|c|}
\hline \multirow{2}{*}{ Class Genera } & \multicolumn{2}{|c|}{ Sites } & \multicolumn{2}{|c|}{ Months } & \multicolumn{2}{|c|}{ Months $\times$ Sites } \\
\hline & $\mathrm{F}$ & $\mathrm{P}$ & $\mathrm{F}$ & $\mathrm{P}$ & $\mathrm{F}$ & $\mathrm{P}$ \\
\hline Chrysophyta & 34.95 & $<0.0001$ & 23.11 & $<0.0001$ & 3.65 & 0.079 \\
\hline Navicula & 1.79 & 0.206 & 0.87 & 0.557 & 10.29 & 0.0069 \\
\hline Synedra & 29.03 & $<0.0001$ & 31.66 & $<0.0001$ & 0.01 & 0.934 \\
\hline Melosira & 0.56 & 0.582 & 0.23 & 0.971 & 6.24 & 0.027 \\
\hline Fragilaria & 0.86 & 0.443 & 8.97 & 0.0003 & 0.65 & 0.433 \\
\hline Cymbella & 3.27 & 0.069 & 3.43 & 0.024 & 4.20 & 0.061 \\
\hline Amphora & 0.09 & 0.919 & 0.60 & 0.747 & 6.10 & 0.028 \\
\hline Cyanophyta & 5.99 & 0.013 & 4.81 & 0.0061 & 0.77 & 0.40 \\
\hline Oscillatoria & 1.21 & 0.326 & 1.04 & 0.448 & 0.50 & 0.491 \\
\hline Anabaena & 4.75 & 0.027 & 4.69 & 0.0069 & 4.10 & 0.064 \\
\hline Chroococcus & 0.07 & 0.932 & 1.00 & 0.474 & 8.52 & 0.012 \\
\hline Chlorophyta & 11.22 & 0.0012 & 6.57 & 0.0014 & 2.73 & 0.076 \\
\hline Staurastrum & 0.21 & 0.816 & 1.36 & 0.298 & 16.36 & 0.0014 \\
\hline Scendesmus & 0.01 & 0.992 & 0.79 & 0.606 & 8.49 & 0.012 \\
\hline Pyrrophyta & 11.05 & 0.0013 & 4.45 & 0.0085 & 1.78 & 0.206 \\
\hline Peridinium & 11.05 & 0.0013 & 4.45 & 0.0085 & 1.78 & 0.206 \\
\hline Total phytoplankton & 50.76 & $<0.0001$ & 25.53 & $<0.0001$ & 2.61 & 0.130 \\
\hline
\end{tabular}

Table S7. Results from canonical correlation analysis (CCA) between water quality parameters and planktons on three sampling sites in the Kulekhani Multipurpose Reservoir, Nepal.

\begin{tabular}{|c|c|c|c|c|c|c|c|c|}
\hline Canonical variate & \multicolumn{2}{|c|}{$\begin{array}{c}\text { CC between water } \\
\text { quality and zooplankton }\end{array}$} & Canonical variate & $\begin{array}{c}\text { CC between water } \\
\text { quality and } \\
\text { phytoplankton }\end{array}$ & $\begin{array}{c}\text { Canonical } \\
\text { variate }\end{array}$ & \multicolumn{3}{|c|}{$\begin{array}{l}\text { CC between phytoplankton and } \\
\text { zooplankton }\end{array}$} \\
\hline 1 & \multicolumn{2}{|c|}{$0.98^{\mathrm{a}}$} & 1 & $0.99^{\mathrm{b}}$ & 1 & & $0.99^{\mathrm{a}}$ & \\
\hline \multirow[t]{3}{*}{2} & \multicolumn{2}{|c|}{$0.97^{\mathrm{a}}$} & & & 2 & & $0.98^{\mathrm{a}}$ & \\
\hline & & & & & 3 & & $0.98^{\mathrm{a}}$ & \\
\hline & Water 1 & Water 2 & & Water 1 & & Phyto 1 & Phyto 2 & Phyto 3 \\
\hline Transparency & -0.49 & 0.04 & Transparency & 0.42 & Navicula & 0.04 & 0.40 & 0.32 \\
\hline Temperature & 0.38 & 1.24 & Temperature & -0.02 & Synedra & 0.62 & -0.16 & 0.25 \\
\hline $\mathrm{pH}$ & 0.02 & 0.12 & $\mathrm{pH}$ & 0.01 & Melosira & 0.17 & 0.52 & -0.65 \\
\hline DissolvedOxygen & -0.41 & 0.39 & DissolvedOxygen & 0.50 & Fragilaria & 0.73 & -0.29 & -0.85 \\
\hline Carbondioxide & 0.05 & 0.98 & Carbondioxide & 0.31 & Cymbella & -0.24 & 0.01 & 0.06 \\
\hline Alkalinity & 0.27 & -0.21 & Alkalinity & 0.70 & Amphora & -0.18 & -0.10 & 0.47 \\
\hline Totalhardness & -0.03 & 0.32 & Totalhardness & -0.20 & Oscillatoria & -0.25 & 0.40 & -0.33 \\
\hline Nitrate & 0.26 & -0.67 & Nitrate & -0.34 & Anabaena & -0.11 & -0.91 & 0.41 \\
\hline
\end{tabular}




\section{Continued}

\begin{tabular}{|c|c|c|c|c|c|c|c|c|}
\hline \multirow[t]{5}{*}{ Phosphate } & -0.26 & 0.63 & Phosphate & 0.01 & Chroococcus & 0.02 & 1.26 & 0.23 \\
\hline & & & & & Staurastrum & -0.09 & 0.26 & 0.24 \\
\hline & & & & & Scendesmus & -0.14 & 0.25 & 0.37 \\
\hline & & & & & Peridinium & -0.05 & -0.79 & 0.46 \\
\hline & Zoo1 & Zoo2 & & Phyto1 & & Zool & Zoo2 & Zoo3 \\
\hline Cyclops & 0.68 & -0.34 & Navicula & -0.41 & Cyclops & 1.38 & -0.17 & -0.75 \\
\hline Nauplius & 0.56 & -1.14 & Synedra & 0.29 & Nauplius & -0.98 & -0.44 & 1.25 \\
\hline Daphnia & -0.26 & 0.87 & Melosira & 1.14 & Daphnia & -0.75 & 0.96 & 0.33 \\
\hline Bosmina & -0.35 & -0.31 & Fragilaria & 0.07 & Bosmina & -0.50 & 0.39 & 0.63 \\
\hline Alona & -0.07 & 0.80 & Cymbella & -0.99 & Alona & 0.15 & -0.19 & -0.68 \\
\hline Moina & 0.49 & 0.90 & Amphora & 0.59 & Moina & -0.29 & 0.67 & 0.25 \\
\hline Keratella & 0.17 & 0.09 & Oscillatoria & 0.04 & Keratella & 0.01 & 0.19 & -1.01 \\
\hline Polyanthra & -0.54 & 1.11 & Anabaena & -1.02 & Polyanthra & 0.06 & 0.28 & -0.28 \\
\hline Pompholyx & 0.10 & -0.92 & Chroococcus & 0.65 & Pompholyx & 0.02 & 0.42 & 0.49 \\
\hline Asplachana & -0.05 & 0.75 & Staurastrum & -0.33 & Asplachana & 0.61 & -0.56 & 0.52 \\
\hline \multirow[t]{2}{*}{ Brachionus } & 0.35 & -0.44 & Scendesmus & -1.15 & Brachionus & 0.54 & -0.99 & 0.68 \\
\hline & & & Peridinium & 0.31 & & & & \\
\hline $\begin{array}{c}\text { Cumulative \% of } \\
\text { variance explained }\end{array}$ & 48.1 & 77.9 & & 77.5 & & 97.7 & 98.9 & 99.6 \\
\hline
\end{tabular}

${ }^{\text {aSignificant }}(\mathrm{P} \leq 0.05)$. ${ }^{\text {bSignificant }}(\mathrm{P} \leq 0.1)$. 